\title{
SCIENTIFIC REPORTS

\section{OPEN Co-inoculation effect of Rhizobium and Achillea millefolium L. oil extracts on growth of common bean (Phaseolus vulgaris L.) and soil microbial-chemical properties}

\author{
Veysel Turan $\mathbb{1}^{1,2^{*}}$, Peter Schröder $\mathbb{D}^{3}$, Serdar Bilen $\mathbb{B}^{4}$, Heribert Insam $\mathbb{1}^{1}$ \& \\ Marina Fernández-Delgado Juárez $\mathbb{D}^{1}$
}

Essential oils (EO) of several plant species have the potential to combat plant and fungal diseases. However, the effects of Achillea millefolium EO on the development of common bean (Phaseolus vulgaris $\mathrm{L}$.), is still unknown. Moreover, its effect on $\mathrm{N}_{2}$-fixing bacteria, and in general on soil properties has not been studied yet. A greenhouse trial was set up to evaluate both the influence that Achillea millefolium EO and the inoculation with three different Rhizobium strains have on the bean plant and on the chemical and microbiological properties of an agriculturally used Cambisol. Non-inoculated pots were used as control. Our findings showed a decrease in bacterial colony forming units due to EO application and an increase following the Rhizobium inoculation compared to the control. The EO application decreased soil basal respiration and activities of dehydrogenase, urease, $\beta$-glucosidase and acid phosphatase. Such effects were stronger with higher oil concentrations. Moreover, the treatments combining Rhizobium inoculation with EO showed a positive effect on nodulation and plant height. Overall, the combined application of Achillea millefolium EO and rhizobia works as an efficient biocide that could be applied in organic agriculture without hampering the activity of nodule-forming $\mathrm{N}$-fixing bacteria and the development of common bean.

It is expected that the world population will reach 9.8 billion people by 2050 , and 11.2 billion in 2100 according to the United Nations ${ }^{1}$, and thus global agriculture will be intensified to feed the increasing population. Enhancing the productivity of agricultural systems while substantially reducing environmental impact is a worldwide responsibility in order to ensure food security for future generations.

Common bean (Phaseolus vulgaris L.) is one of the most important legumes in the world ${ }^{2}$. In areas of Eastern Africa and Latin America, this plant contributes to 65\% of the total protein consumed and 32\% of the energy intake ${ }^{3}$. Moreover, it has been estimated that approximately 26 million metric tons of beans were produced worldwide in $2016^{4}$, being a crucial crop in developing countries ${ }^{5}$. In developing areas, a sustainable practice to enhance common bean production consists in their inoculation with symbiotic and associative bacteria to enhance plant growth ${ }^{6}$.

Plant oils have been used for thousands of years for several purposes ${ }^{7}$ and are in ever increasing demand nowadays as an alternative medicine. Previous scientific studies have related essential oil compounds to their medical effectivity $^{8}$. Another use for plant-essential oils is in the food industry due to their antibacterial, antifungal, antiviral, and antioxidant properties ${ }^{9}$. However, in agriculture, their application is connected to plant protection ${ }^{10}$ and for their further use as eco-friendly pesticides ${ }^{11-13}$. The essential oils of Achillea species have been the subject of several studies in which their therapeutic, cosmetic, and fragrant properties have been demonstrated. Işcan et al. ${ }^{14}$

${ }^{1}$ Institute of Microbiology, University of Innsbruck, Innsbruck, Austria. ${ }^{2}$ Department of Soil Science and Plant Nutrition, Faculty of Agriculture, Bingöl University, Bingöl, Turkey. ${ }^{3}$ Department of Microbe-Plant Interactions, Helmholtz Zentrum München, German Research Center for Environmental Health GmbH Neuherberg, Oberschleißheim, Germany. ${ }^{4}$ Department of Soil Science and Plant Nutrition, Faculty of Agriculture, Atatürk University, Erzurum, Turkey. *email: vturan@bingol.edu.tr 


\begin{tabular}{|l|l|l|}
\hline Parameters & Units & Values \\
\hline Sand & $\%$ & $21.7 \pm 1.0$ \\
\hline Silt & $\%$ & $46.4 \pm 0.9$ \\
\hline Clay & $\%$ & $31.9 \pm 1.9$ \\
\hline Organic Matter & $\%$ & $3.28 \pm 0.1$ \\
\hline $\mathrm{CaCO}_{3}$ & $\%$ & $0.47 \pm 0.1$ \\
\hline $\mathrm{pH}$ & - & $6.50 \pm 0.1$ \\
\hline EC $^{\mathrm{a}}$ & $\mathrm{dS} \mathrm{m}^{-1}$ & $0.52 \pm 0.1$ \\
\hline $\mathrm{CEC}^{\mathrm{b}}$ & $\mathrm{cmol}_{\mathrm{c}} \mathrm{kg}^{-1}$ & $35.7 \pm 0.8$ \\
\hline Phosphorus & $\mathrm{mg} \mathrm{kg}^{-1}$ & $9.78 \pm 0.1$ \\
\hline Total Nitrogen & $\mathrm{mg} \mathrm{kg}^{-1}$ & $250.3 \pm 9.5$ \\
\hline N-Ammonium & $\mathrm{mg} \mathrm{kg}^{-1}$ & $19.1 \pm 1.2$ \\
\hline N-Nitrate & $\mathrm{mg} \mathrm{kg}^{-1}$ & $29.9 \pm 0.6$ \\
\hline
\end{tabular}

Table 1. Physiochemical properties of the soil used in this study. Values are given on a dry weight basis as an average of $\mathrm{n}=3 \pm$ standard deviation. ${ }^{a}$ Electrical conductivity. ${ }^{\mathrm{b}}$ Cation exchange capacity.

studied the antimicrobial properties of several plants of the Achillea genus and found that the Achillea aleppica subsp. aleppica had moderate antimicrobial activity, similar to Achillea millefolium. Along these lines, Stojanovic et al. ${ }^{15}$ evaluated the in vitro antimicrobial effect of four different Achillea species confirming the antibacterial and fungicidal effect of Achillea millefolium. Despite the proven effect of Achillea essential oils in the medical field, their potential application in agriculture has not been studied yet, potentially opening a promising door for future applications, especially in biologically and dynamically managed agricultural fields.

It is widely known that diazotrophic bacteria, among them rhizobia, promote biological nitrogen (N) fixation resulting in better plant development ${ }^{16,17}$. Moreover, previous studies dealing with the effect of Rhizobium inoculation on plants have focused on soil and soil mineral $\mathrm{N}$ content ${ }^{18}$, nodulation ${ }^{19}$, nitrogen fixation ${ }^{20}$, plant height ${ }^{21}$ and plant growth ${ }^{22}$. All of these parameters are crucial to assess if the soil-microbe-plant interaction shall lead to enhanced plant performance.

The use of bacteria from the genus Rhizobium has been shown to be an environment-friendly alternative to mineral nitrogen fertilizers, due to their positive effects on plant nodulation, biological N-fixation and consequently $\mathrm{N}$-availability. Although the fixed nitrogen is not readily available to the plant, inoculation ensures long-term $\mathrm{N}$-availability in soil, thus, being an ecologically viable option for amelioration of agricultural soils ${ }^{23}$. In line with this, inoculation of Rhizobium sp. BARIRGm901 in gray terrace soils led to higher nitrogen fixation and yield of soybean (Glycine max) ${ }^{24}$. Moreover, Rhizobium inoculation does not only affect the plant performance but also the soil microbiota; indeed, Fall et al. ${ }^{25}$ found that Rhizobium inoculation on a Gum Arabic production area with natural trees of Senegalia senegal (L.) Britton, (synonym: Acacia senegal) led to an increase in soil microbial biomass and respiration as well as mineral nitrogen content; and positive effect on soil microbial functional diversity was also observed ${ }^{25}$. Numerous studies have examined the influence of plant essential oils with regard to plant protection as biological control agents, either alone or in combination with alternative fungicides. However, there is still scarce information on how soil productivity and plant growth are affected by the application of essential oils alone or in combination with Rhizobium, and if these affect the microbiota in an antagonistic or synergistic way.

The aims of the present study were to investigate the effects of Achillea millefolium essential oil and inoculation with different Rhizobium strains on soil biological properties as well as on the growth of bean (Phaseolus vulgaris L.) and its nutrient content. For this purpose, we determined the effects on soil enzyme activities, soil microbial biomass and respiration, plant biomass and plant nutrient content $(\mathrm{N})$, together with soil nutrient content (e.g. mineral N) and plant root nodulation.

\section{Material and Methods}

Experimental setup. Soil sampling. In the present study, a factorial greenhouse pot experiment was set up in July, 2013 in the Helmholtz Zentrum München - German Research Center for Environmental Health (Neuherberg, Germany). The soil used was collected on a research farm in the municipality of Scheyern (Germany, $48^{\circ} 29^{\prime} 54.1^{\prime \prime} \mathrm{N} 11^{\circ} 26^{\prime} 21.3^{\prime \prime} \mathrm{E}$ ). It was classified as $\mathrm{Cambisol}^{26}$, and its main physiochemical properties are shown in Table 1. After the sampling, the soil was air-dried, sieved $(\varnothing<2 \mathrm{~mm})$, and sterilized by autoclaving three consecutive times at $121^{\circ} \mathrm{C}$ for $30 \mathrm{~min}$, prior to its distribution in sterile pots. After autoclaving, one $\mathrm{kg}$ sterile soil was placed in sterile pots $(20 \mathrm{~cm}$ in diameter and $18 \mathrm{~cm}$ in height).

Essential plant oil preparation. Leaves of Achillea millefolium plants were collected from the research campus at Helmholtz Zentrum München - for Environmental Health (Neuherberg, Germany) in June 2013. Freshly collected leaves were shade-dried at room temperature $\left(22 \pm 1{ }^{\circ} \mathrm{C}\right)$ for $10-15$ days. Afterwards, the dried leaves were ground into a fine powder with a pestle and mortar. $50 \mathrm{gr}$ of the sample was subjected to hydro distillation for $3 \mathrm{~h}$ in $500 \mathrm{~mL}$ distilled water using a Clevenger type apparatus for $4 \mathrm{~h}$ in order to produce essential oil. After distillation, the EO concentration was determined by gas chromatography-mass spectrometry (GC-MS). Concentrated EO (1500 ppm) were then diluted using distilled water to the following concentrations: $0 \mathrm{ppm}: 0 \mathrm{ml} \mathrm{EO} 100 \mathrm{ml}^{-1}$, 100 ppm: $6.66 \mathrm{EO} 100 \mathrm{ml}^{-1}$, and $1000 \mathrm{ppm}$ : $66.6 \mathrm{EO} \mathrm{ml} 100 \mathrm{ml}^{-1}$. 
Rhizobium inoculum preparations. Rhizobium leguminosarum biovar phaseoli cultures were obtained from the laboratory stock culture collection and prepared by sub-culturing in three $\mathrm{mL}$ of YMA (yeast extract-mannitol agar) and incubated at $28^{\circ} \mathrm{C}$ for 5 days. Rhizobial inocula (Rhizobium leguminosarum biovar phaseoli F7, Rhizobium leguminosarum biovar phaseoli F83, Rhizobium leguminosarum biovar phaseoli Ciat 899) were incubated at $30^{\circ} \mathrm{C}$ for three days in YMA, and were posterior used as material for inoculation in this experiment ${ }^{27}$. In order to have equal numbers of bacteria as inoculation material, absorbance values at $540 \mathrm{~nm}$ wavelength were measured spectrophotometrically. To achieve an equal bacterial density, the lowest number of bacteria after $24 \mathrm{~h}$ was taken as a baseline. Where appropriate, bacterial suspensions were diluted to the same absorbance value with sterile physiological saline solution (PSS) ${ }^{27}$.

Greenhouse set up. A total of twelve treatments resulted from combining three different Achillea millefolium essential oil doses (E0 (control), E1 (100 $\left.\mathrm{mg} \mathrm{kg}^{-1}\right)$ and E2 $\left.\left(1000 \mathrm{mg} \mathrm{kg}^{-1}\right)\right)$ per $\mathrm{kg}$ of pot soils with three different Rhizobium inocula and a non-inoculated control (R0: No inoculation; R1: Rhizobium leguminosarum biovar phaseoli F7; R2: Rhizobium leguminosarum biovar phaseoli F83; R3: Rhizobium leguminosarum biovar phaseoli Ciat 889). All treatments were done in triplicate, with a total of 36 pots.

- R0 E0 No inoculation/No essential oil

- R0 E1 No inoculation/essential oil (100 $\left.\mathrm{mg} \mathrm{kg}^{-1}\right)$

- R0 E2 No inoculation/essential oil (1000 $\left.\mathrm{mg} \mathrm{kg}^{-1}\right)$

- R1 E0 Rhizobium leguminosarum biovar phaseoli F7/No essential oil

- R1 E1 Rhizobium leguminosarum biovar phaseoli F7/essential oil $\left(100 \mathrm{mg} \mathrm{kg}^{-1}\right)$

- R1 E2 Rhizobium leguminosarum biovar phaseoli F7/essential oil (1000 $\mathrm{mg} \mathrm{kg}^{-1}$ )

- R2 E0 Rhizobium leguminosarum biovar phaseoli F83/No essential oil

- R2 E1 Rhizobium leguminosarum biovar phaseoli F83/essential oil (100 $\left.\mathrm{mg} \mathrm{kg}^{-1}\right)$

- R2 E2 Rhizobium leguminosarum biovar phaseoli F83/essential oil (1000 $\mathrm{mg} \mathrm{kg}^{-1}$ )

- R3 E0 Rhizobium leguminosarum biovar phaseoli Ciat 889/No essential oil

- R3 E1 Rhizobium leguminosarum biovar phaseoli Ciat 889/essential oil (100 $\left.\mathrm{mg} \mathrm{kg}^{-1}\right)$

- $\quad$ R3 E2 Rhizobium leguminosarum biovar phaseoli Ciat 889/essential oil (1000 $\left.\mathrm{mg} \mathrm{kg}^{-1}\right)$

Phaseolus vulgarts L seeds were surface-sterilized in $5 \% \mathrm{H}_{2} \mathrm{O}_{2}$ for 15 minutes and rinsed 5 times with sterile distilled water. After the soils were potted, each pot was planted with three sterile seeds. After seedling, the two seedlings showing the weakest growth were removed 7 days after planting. The essential oils were diluted $(0,100$ and $1000 \mathrm{ppm}$ ) with $10 \mathrm{ml}$ ethyl alcohol and were slowly surface-sprayed. Seven days after planting, each seedling was inoculated with one $\mathrm{mL}$ of $\log$ phase bacterial culture with the help of a sterile syringe on the soil surface in the root area. During the 45-day incubation period, soil moisture content was kept at field capacity. The pots were irrigated with water containing bacterial culture suspensions (diluted to $1 \times 10^{9}$ cells in each pot) to $55-60 \%$ of the soil water-holding capacity. Soils were maintained at this moisture level by watering them to weight every 2-3 days. After the incubation period, plants were removed from the pots and soil samples were collected and kept at $4^{\circ} \mathrm{C}$ prior to analysis.

Soil physico-chemical analyses. Soil electrical conductivity (EC) and $\mathrm{pH}$ were determined in $10 \mathrm{~g}$ of soil in combination with $25 \mathrm{~mL}$ A.d. at a ratio of 1:2.5. Soil texture was analyzed according to Bouyoucos ${ }^{28}$. Soil cation exchange capacity (CEC) and organic matter (OM) were analyzed as described in Sumner and Miller ${ }^{29}$ and Nelson and Sommers ${ }^{30}$ respectively. Soil inorganic nitrogen $\left(\mathrm{N}-\mathrm{NH}_{4}{ }^{+}\right.$and $\left.\mathrm{N}_{-} \mathrm{NO}_{3}{ }^{-}\right)$was determined in $2 \mathrm{M} \mathrm{KCl}$ extracts according to Bremmer and Keeney ${ }^{31}$. To determine extractable inorganic $\mathrm{P}$, soil samples were extracted with $0.5 \mathrm{M} \mathrm{NaHCO}_{3}(\mathrm{pH} \mathrm{8.5)}$ for $30 \mathrm{~min}$, and $\mathrm{P}$ was measured following the method proposed by Olsen and Sommers ${ }^{32}$.

Soil biological analyses. Soil bacterial and fungal abundance. Bacterial and fungal abundance in the soil samples were assessed by determining colony forming units (CFU). One g of soil was extracted in $9 \mathrm{~mL}$ phosphate buffered saline (PBS) in a rotation shaker for $30 \mathrm{~min}$. Samples were diluted $10^{-6}$ and $10^{-7}$, and $100 \mu \mathrm{L}$ of each sample was then plated on soil extract medium and dextrose-peptone agar for bacteria and fungi, respectively. Bacterial plates were incubated at $30^{\circ} \mathrm{C}$, and fungal ones at $25^{\circ} \mathrm{C}$ for a total of seven days ${ }^{33}$. In the case of bacterial colonies, the average CFUs per gram of oven-dried equivalent (ODE) of field-moist soil was calculated by using an automated colony counter ${ }^{34,35}$. Fungal colonies growing in agar were observed under a dissecting microscope. They were then marked and recorded in the surface agar. Total culturable fungi were calculated by viable fungal spore $\mathrm{g}^{-1}$ of oven dry soil ${ }^{36}$. It has to be addressed that this culture-dependent method is biased because it generally underestimates the total cell number by a factor of $10-100^{37}$.

Soil microbial activity. Soil basal respiration (BR) was determined according to Islam and Weil ${ }^{38}$. Briefly, the $\mathrm{CO}_{2}$ released from $20-25 \mathrm{~g}$ moist soil sample previously incubated at $25 \pm 1{ }^{\circ} \mathrm{C}$ for $24 \mathrm{~h}$ was then trapped in $20 \mathrm{~mL}$ of $0.5 \mathrm{M} \mathrm{NaOH}$ solution. Afterwards, $\mathrm{BaCl}_{2}$ was added to precipitate the $\mathrm{CO}_{2}$ as $\mathrm{BaCO}_{3}$, followed by a titration with $0.5 \mathrm{M} \mathrm{HCl}$.

Soil enzyme activities. Five soil enzyme activities were measured: acid phosphatase (AcdP) and alkaline phosphatase (AlkP) activities were assessed by using pNPP (para-Nitrophenyl phosphate) as substrate and expressed as $\mu \mathrm{g} \mathrm{pNP} \mathrm{g} \mathrm{DM}{ }^{-1} \mathrm{~h}^{-1}$ following the method of Tabatabai ${ }^{39}$. Soil urease (UE) activity was determined using the steam distillation methods as described by Tabatabai and Bremner ${ }^{40}$ using urea as substrate and expressed as $\mu g \mathrm{NH}_{4}-\mathrm{N}$ $\mathrm{g} \mathrm{DM}^{-1} 2 \mathrm{~h}^{-1}$. $\beta$-glucosidase activity ( $\beta$-Glu) was assayed using $\beta$-PNPGLU (p-Nitrophenyl- $\beta$-D-glucopyranoside) 


\begin{tabular}{|c|c|c|c|c|c|c|c|}
\hline \multicolumn{2}{|l|}{ Treatments } & \multicolumn{6}{|l|}{ Parameters } \\
\hline Inoculation & \begin{tabular}{|l|} 
Essential \\
Oil
\end{tabular} & $\begin{array}{l}\text { Total N } \\
(\%)\end{array}$ & $\begin{array}{l}\mathrm{NO}_{3}^{-} \\
\left(\mu \mathrm{g} \mathrm{N} \mathrm{g}^{-1}\right)\end{array}$ & $\begin{array}{l}\mathrm{NH}_{4}^{ \pm} \\
\left(\mu \mathrm{g} \mathrm{N} \mathrm{g}^{-1}\right)\end{array}$ & \begin{tabular}{|l|} 
Bacterial abundance \\
$($ CFU g \\
$-1)$
\end{tabular} & $\begin{array}{l}\text { Fungal abundance } \\
\left(\text { CFU g }{ }^{-1}\right)\end{array}$ & $\begin{array}{l}\text { Basal respiration } \\
\left(\mu \mathrm{g} \mathrm{C} g^{-1} h^{-1}\right)\end{array}$ \\
\hline \multirow{3}{*}{$\begin{array}{l}\text { No inoculation } \\
\text { (R0) }\end{array}$} & E0 & $0.19 \pm 0.01$ & $55.1 \pm 18.0$ & $15.3 \pm 0.6$ & $3.34 \cdot 10^{7} \pm 8.91 \cdot 10^{6} \mathrm{ab}$ & $5.50 \cdot 10^{6} \pm 0.12 \cdot 10^{6} \mathrm{a}$ & $24.9 \pm 0.4 \mathrm{a}$ \\
\hline & E1 & $0.20 \pm 0.01$ & $43.3 \pm 6.9$ & $12.8 \pm 3.3$ & $3.78 \cdot 10^{7} \pm 7.55 \cdot 10^{6} \mathrm{a}$ & $5.53 \cdot 10^{6} \pm 3.73 \cdot 10^{6} \mathrm{a}$ & $17.0 \pm 3.0 \mathrm{~b}$ \\
\hline & E2 & $0.21 \pm 0.01$ & $34.1 \pm 6.3$ & $17.0 \pm 11.8$ & $1.35 \cdot 10^{7} \pm 1.38 \cdot 10^{6} \mathrm{~b}$ & $3.16 \cdot 10^{6} \pm 1.38 \cdot 10^{6} \mathrm{~b}$ & $13.7 \pm 2.8 \mathrm{~b}$ \\
\hline \multirow{3}{*}{$R 1$} & E0 & $0.20 \pm 0.02$ & $46.8 \pm 20.5$ & $16.6 \pm 6.4$ & $2.65 \cdot 10^{7} \pm 2.38 \cdot 10^{6} \mathrm{a}$ & $6.06 \cdot 10^{6} \pm 0.21 \cdot 10^{6} \mathrm{~b}$ & $26.5 \pm 2.8 \mathrm{a}$ \\
\hline & E1 & $0.18 \pm 0.06$ & $67.6 \pm 29.8$ & $17.5 \pm 4.2$ & $0.74 \cdot 10^{7} \pm 4.17 \cdot 10^{6} \mathrm{~b}$ & $9.73 \cdot 10^{6} \pm 4.17 \cdot 10^{6} \mathrm{a}$ & $17.2 \pm 3.4 \mathrm{~b}$ \\
\hline & E2 & $0.18 \pm 0.03$ & $60.1 \pm 26.1$ & $12.7 \pm 2.7$ & $0.82 \cdot 10^{7} \pm 0.71 \cdot 10^{6} \mathrm{~b}$ & $4.16 \cdot 10^{6} \pm 0.71 \cdot 10^{6} \mathrm{c}$ & $13.3 \pm 5.4 \mathrm{~b}$ \\
\hline \multirow{3}{*}{$R 2$} & E0 & $0.20 \pm 0.01$ & $42.0 \pm 17.5$ & $21.0 \pm 3.6$ & $1.43 \cdot 10^{7} \pm 9.37 \cdot 10^{6} \mathrm{a}$ & $3.73 \cdot 10^{6} \pm 1.37 \cdot 10^{6} \mathrm{c}$ & $15.5 \pm 4.8 \mathrm{a}$ \\
\hline & E1 & $0.19 \pm 0.02$ & $55.6 \pm 23.3$ & $14.6 \pm 1.5$ & $0.69 \cdot 10^{7} \pm 1.82 \cdot 10^{6} \mathrm{c}$ & $4.63 \cdot 10^{6} \pm 1.82 \cdot 10^{6} \mathrm{~b}$ & $17.3 \pm 1.6 \mathrm{a}$ \\
\hline & E2 & $0.20 \pm 0.01$ & $43.9 \pm 9.4$ & $11.5 \pm 0.8$ & $1.32 \cdot 10^{7} \pm 0.53 \cdot 10^{6} \mathrm{~b}$ & $16.1 \cdot 10^{6} \pm 2.20 \cdot 10^{6} \mathrm{a}$ & $15.4 \pm 1.5 \mathrm{a}$ \\
\hline \multirow{3}{*}{$R 3$} & E0 & $0.19 \pm 0.03$ & $48.9 \pm 4.0$ & $15.7 \pm 2.4$ & $7.60 \cdot 10^{7} \pm 1.83 \cdot 10^{6} \mathrm{a}$ & $7.60 \cdot 10^{6} \pm 3.16 \cdot 10^{6} \mathrm{a}$ & $14.5 \pm 2.8 \mathrm{~b}$ \\
\hline & E1 & $0.20 \pm 0.02$ & $52.1 \pm 8.5$ & $24.3 \pm 11.6$ & $2.65 \cdot 10^{7} \pm 2.40 \cdot 10^{6} \mathrm{~b}$ & $2.65 \cdot 10^{6} \pm 1.08 \cdot 10^{6} \mathrm{c}$ & $13.5 \pm 1.45 \mathrm{c}$ \\
\hline & E2 & $0.22 \pm 0.02$ & $34.3 \pm 7.1$ & $15.7 \pm 1.2$ & $1.39 \cdot 10^{7} \pm 2.19 \cdot 10^{6} \mathrm{c}$ & $5.90 \cdot 10^{6} \pm 3.67 \cdot 10^{6} \mathrm{~b}$ & $23.7 \pm 7.2 \mathrm{a}$ \\
\hline
\end{tabular}

Table 2. Effects of different rates of essential oil (E0: No essential oil; E1: essential oil ( $\left.100 \mathrm{mg} \mathrm{kg}^{-1}\right)$, E2: essential oil (1000 $\left.\mathrm{mg} \mathrm{kg}^{-1}\right)$ ) and different Rhizobium inocula (R0: No inoculation, R1: Rhizobium leguminosarum biovar phaseoli F7, R2: Rhizobium leguminosarum biovar phaseoli F83, R3: Rhizobium leguminosarum biovar phaseoli Ciat899) on soil chemical and microbial properties. Different letters indicate significant differences followed by Tukey post- hoc test considering essential oil application for each inoculation treatment and interaction. Values are given as an average for $n=3$ on a dry weight basis \pm standard deviation.

as substrate and expressed as $\mu \mathrm{g}$ PNP $\mathrm{g} \mathrm{DM}^{-1} \mathrm{~h}^{-139}$. Dehydrogenase (DH) activity was determined with the TTC (triphenyl tetrazolium chloride) method $^{39}$ and expressed as $\mu \mathrm{g} \mathrm{TPF} \mathrm{g} \mathrm{DM}^{-1} 24 \mathrm{~h}^{-1}$.

Plant analyses. The growth response (plant height), total plant biomass, nodule number, and plant total $\mathrm{N}$-content were measured in this experiment, as these parameters are well-known to show a quick response when plants are inoculated with nodule-forming N-fixing bacteria. Both the aboveground (leaf and stem) and root biomass were collected separately from the experimental pots and washed. Roots were oven-dried at $65^{\circ} \mathrm{C}$ for $72 \mathrm{~h}$, while leaves and stems were dried for $48 \mathrm{~h}$ to determine their dry matter content. After the plant harvest, the numbers of nodules per plant were determined in the roots. Total plant nitrogen contents were determined by the Kjeldahl method after salicylic-sulfuric acid digestion ${ }^{41}$.

Statistical analyses. Statistical analyses were performed using the SPSS 23 Software (2015, IBM Corp. Armonk, NY, USA). Data were analyzed using a two-way analysis of variance (ANOVA). When significant differences were obtained, an analysis with Tukey's HSD (honestly significant difference) comparison procedure was further performed as a post hoc test. Prior to analysis, data were tested for normality and transformed to meet this condition when necessary. When data did not meet the normality assumption, they were subjected to non-parametric tests for several independent samples (Kruskal-Wallis test) and pair-wise comparisons were performed using the non-parametric Friedman test.

\section{Results}

Influence of essential oil and Rhizobium inoculation on soil chemical properties. The inoculation of soil with different Rhizobium strains and the application of different doses of Achillea millefolium essential oil as well as their interaction did not induce significant effects $(p>0.05)$ on different soil N-pools (nitrate, ammonium and total N) (Tables 2 and 4). Despite there were no significant effects of the different treatments on the soil ammonium content, soils inoculated with R2 and R3 had higher ammonium contents than the remaining soils. A similar trend was recorded for the soil nitrate content for which no significant differences were recorded among treatments (Tables 2 and 4). In particular, for soils inoculated with Rhizobium species (R1, R2, and R3) the application of E1 induced an increase in the nitrate content, while no such increase was observed for E2.

Influence of essential oil and Rhizobium inoculation on soil biological properties. The application of essential oil doses to the soils significantly decreased bacterial abundance (Tables 2 and $4 ; p<0.001$ ), as did the inoculation with different Rhizobium strains $(p<0.001)$. Moreover, a significant interaction between the application of essential oil and Rhizobium strains $(p<0.001)$ was also found (Table 4$)$. The bacterial abundance increased for R3 strain, but not for R1 and R2 strains, compared to the control pots where no essential oil was added (E0). The addition of essential oils to the soils induced a significant decrease in bacterial CFUs. When oil at a concentration of $100 \mathrm{ppm}$ was added (E1), a reduction of approximately $30 \%$ in bacterial CFUs was observed in all the inoculation treatments (R1, R2, R3), but not for the non-inoculated one (Table 2). The application of a dose 10 times higher (E2) only induce a further decrease for R2 and R3 treatments. Contrarily to what was observed for bacterial CFUs, only the interaction between the application of essential oil and Rhizobium strains $(p<0.001)$ was found to affect soil fungal CFUs (Table 4). Each combination of oil treatments $\mathrm{x}$ Inoculation affected the soil fungal abundance differently (Table 2). For the control soils, only high oil doses of $1000 \mathrm{ppm}$ (E2) induced a decrease in the fungal abundance. In the case of R1 and R2 treatments, less concentrated oil application (E1) enhanced the fungal CFUs, while higher concentrations (E2) significantly decreased the number of culturable 


\begin{tabular}{|c|c|c|c|c|c|}
\hline \multicolumn{2}{|l|}{ Treatments } & \multicolumn{4}{|c|}{ Plant parameters of Phaseolus vulgaris L. } \\
\hline Inoculation & Essential Oil & Nodules & $\begin{array}{l}\text { Plant height } \\
(\mathrm{cm})\end{array}$ & \begin{tabular}{|l|} 
Total plant \\
biomass (g DW)
\end{tabular} & $\begin{array}{l}\text { Plant } \mathrm{N} \text { content } \\
\left(\mathrm{g} \mathrm{kg}^{-1}\right)\end{array}$ \\
\hline \multirow{3}{*}{$\begin{array}{l}\text { No inoculation } \\
\text { (R0) }\end{array}$} & E0 & $0 \pm 0.0 \mathrm{a}$ & $35.3 \pm 1.5$ & $2.96 \pm 0.6$ & $1.70 \pm 0.5$ \\
\hline & E1 & $0 \pm 0.0 \mathrm{a}$ & $34.3 \pm 1.5$ & $2.87 \pm 0.4$ & $1.80 \pm 1.1$ \\
\hline & E2 & $0 \pm 0.0 \mathrm{a}$ & $27.0 \pm 2.0$ & $2.78 \pm 0.7$ & $1.98 \pm 0.5$ \\
\hline \multirow{3}{*}{$R 1$} & E0 & $22.7 \pm 6.6 \mathrm{a}$ & $36.3 \pm 9.5 \mathrm{a}$ & $3.31 \pm 0.8$ & $2.24 \pm 0.8$ \\
\hline & E1 & $36.7 \pm 9.0 \mathrm{~b}$ & $28.3 \pm 1.5 \mathrm{~b}$ & $3.22 \pm 0.9$ & $2.42 \pm 0.5$ \\
\hline & E2 & $29.0 \pm 1.7 \mathrm{ab}$ & $39.0 \pm 9.2 \mathrm{a}$ & $3.39 \pm 0.7$ & $2.49 \pm 1.4$ \\
\hline \multirow{3}{*}{$R 2$} & E0 & $48.3 \pm 2.8 \mathrm{a}$ & $31.0 \pm 10.5 \mathrm{a}$ & $3.81 \pm 0.8$ & $1.66 \pm 0.8$ \\
\hline & E1 & $40.7 \pm 9.3 \mathrm{~b}$ & $26.0 \pm 3.6 \mathrm{~b}$ & $3.63 \pm 0.8$ & $2.17 \pm 0.9$ \\
\hline & E2 & $44.0 \pm 3.6 \mathrm{ab}$ & $35.0 \pm 7.5 \mathrm{a}$ & $3.49 \pm 1.7$ & $2.69 \pm 1.4$ \\
\hline \multirow{3}{*}{ R3 } & E0 & $46.3 \pm 2.9 \mathrm{a}$ & $48.0 \pm 1.0 \mathrm{a}$ & $3.94 \pm 1.0$ & $2.58 \pm 1.0$ \\
\hline & E1 & $54.0 \pm 3.0 \mathrm{~b}$ & $42.0 \pm 6.2 \mathrm{~b}$ & $3.89 \pm 0.9$ & $2.45 \pm 1.3$ \\
\hline & E2 & $51.0 \pm 1.00 \mathrm{ab}$ & $47.0 \pm 2.6 \mathrm{a}$ & $3.54 \pm 0.9$ & $3.05 \pm 1.7$ \\
\hline
\end{tabular}

Table 3. Effects of different rates of essential oil (E0: No essential oil; E1: essential oil (100 $\left.\mathrm{mg} \mathrm{kg}^{-1}\right)$, E2: essential oil $\left(1000 \mathrm{mg} \mathrm{kg}^{-1}\right)$ ) and different Rhizobium inocula (R0: No Inoculation, R1: Rhizobium leguminosarum biovar phaseoli F7, R2: Rhizobium leguminosarum biovar phaseoli F83, R3: Rhizobium leguminosarum biovar phaseoli Ciat899) on nodules, plant height, total plant biomass and plant $\mathrm{N}$ content. Different letters indicate significant differences followed by Tukey post- hoc test considering essential oil application for each inoculation treatment. Values are given as an average for $\mathrm{n}=3$ on a dry weight basis \pm standard deviation.

\begin{tabular}{|l|l|l|l|l|l|l|}
\hline \multirow{2}{*}{ Parameters } & \multicolumn{2}{|l|}{ Inoculation treatment } & \multicolumn{2}{l|}{ Essential oil treatment } & \multicolumn{2}{l|}{$\begin{array}{l}\text { Inoculation } \times \\
\text { Essential oil }\end{array}$} \\
\cline { 2 - 8 } & $\boldsymbol{F}$ & $\boldsymbol{p}$ & $\boldsymbol{F}$ & $\boldsymbol{p}$ & $\boldsymbol{F}$ & $\boldsymbol{p}$ \\
\hline Total N & n.s. & n.s. & n.s. & n.s. & n.s. & n.s. \\
\hline $\mathrm{NH}_{4}{ }^{+}$ & n.s. & n.s. & n.s. & n.s. & n.s. & n.s. \\
\hline $\mathrm{NO}_{3}{ }^{-}$ & n.s. & n.s. & n.s. & n.s. & n.s. & n.s. \\
\hline Bacterial abundance & 27.8 & $p<0.001$ & 26.6 & $p<0.001$ & 7.74 & $p<0.001$ \\
\hline Fungal abundance & n.s. & n.s. & n.s. & n.s. & 0.28 & $p<0.001$ \\
\hline Basal respiration & n.s. & n.s. & 4.90 & $p<0.05$ & 6.93 & $p<0.001$ \\
\hline
\end{tabular}

Table 4. Two-way analysis of variance (ANOVA) for the soil chemical and microbiological parameters of the soil treated with rhizobial inocula and essential oils as source of variance. n.s.: Not significant.

fungi. Contrarily, a sharp decrease in the fungal CFUs was observed for soil inoculated with the strain R3, ranging from $7.6 \cdot 10^{6}$ to $2.65 \cdot 10^{6}$, when applying a lower dose of essential oil (E1). A lower reduction was found for higher oil concentrations (E2).

As described above for the microbial CFUs, BR was negatively affected by the application of essential oils $(p<0.05)$. In general, the application of the oil extracts decreased of soil basal respiration (Table 2). A significant interaction between both, EO application and inoculation, was also observed $(p<0.001$; Table 4$)$. Both oil doses, $\mathrm{E} 1$ and $\mathrm{E} 2$, reduced BR, from 24.9 to 17.0 and $13.7 \mathrm{mg} \mathrm{C} \mathrm{kg}^{-1} \mathrm{~h}^{-1}$, respectively. A decrease from 26.5 to 17.2 and $13.2 \mathrm{mg} \mathrm{C} \mathrm{kg}^{-1} \mathrm{~h}^{-1}$ was observed for non-inoculated soils and $\mathrm{R} 1$ treatment, respectively. In contrast, when soil was inoculated with R3 BR increased up to $23.7 \mathrm{mg} \mathrm{C} \mathrm{kg}^{-1} \mathrm{~h}^{-1}$ with regard to the higher oil doses (E2: $1000 \mathrm{ppm}$ ) (Table 4).

Regarding the effects of Achillea millefolium L. oil extracts on the activity of the different soil enzyme activities, no effects were observed, except for $\beta$-Glu $(p<0.05)$ for which a reduction was detected compared to the control.

Four of the studied enzymes, that is $\mathrm{DH}, \beta$-Glu, AcdP and urease (UE) showed a significant decline in their activity ( $p<0.001$, for all enzymes), when soil was inoculated with the different Rhizobium strains (Fig. 1). Interestingly, neither the application of oils nor the Rhizobium inoculation affected AlkP. However, AcdP activity reached its maximum value with $\mathrm{R} 1$ treatment $\left(15.5 \pm 1.2 \mu \mathrm{g} \mathrm{pNP} \mathrm{g} \mathrm{DM}{ }^{-1} \mathrm{~h}^{-1}\right)$, while the minimum AcdP activity $\left(10.2 \pm 0.5 \mu \mathrm{g} \mathrm{pNP} \mathrm{g} \mathrm{DM}{ }^{-1} \mathrm{~h}^{-1}\right)$ was observed in the non-inoculated treatment (Fig. 1c). The highest DH activity was found in the $\mathrm{R} 1$ treatment $\left(57.2 \pm 7.4 \mu \mathrm{g} \mathrm{TPF} \mathrm{g} \mathrm{DM}^{-1} 24^{-1}\right)$ that showed double the activity in comparison with the other treatments (Fig. 1a).

Contrarily to the effect observed for AcdP and DH, the highest UE activity $\left(53.9 \pm 6.9 \mu \mathrm{g} \mathrm{NH}_{4}-\mathrm{Ng} \mathrm{DM}^{-1}\right.$ $\left.2 \mathrm{~h}^{-1}\right)$ was observed in the non-inoculated treatment, while the minimum $\mathrm{UE}$ activity $\left(34.4 \pm 3.7 \mu \mathrm{g} \mathrm{NH} \mathrm{N}_{4}-\mathrm{N} \mathrm{g}^{-1}\right.$ $\mathrm{DM}^{-1} 2 \mathrm{~h}^{-1}$ ) was measured in R1 (Fig. 1e). $\beta$-Glu activity was the only soil enzyme activity significantly affected by both the application of essential oil and the inoculation with different Rhizobium strains $(p<0.001$ for both factors). The maximum $\beta$-Glu activity $\left(358 \pm 29 \mu \mathrm{g} \mathrm{PNP} \mathrm{g} \mathrm{DM}{ }^{-1} \mathrm{~h}^{-1}\right)$ was observed in the non-inoculated treatment, while the lowest was found in $\mathrm{R} 3\left(188 \pm 27 \mu \mathrm{g} \mathrm{PNP} \mathrm{g} \mathrm{DM}{ }^{-1} \mathrm{~h}^{-1}\right)$ (Fig. 1b). In line with this, the application 

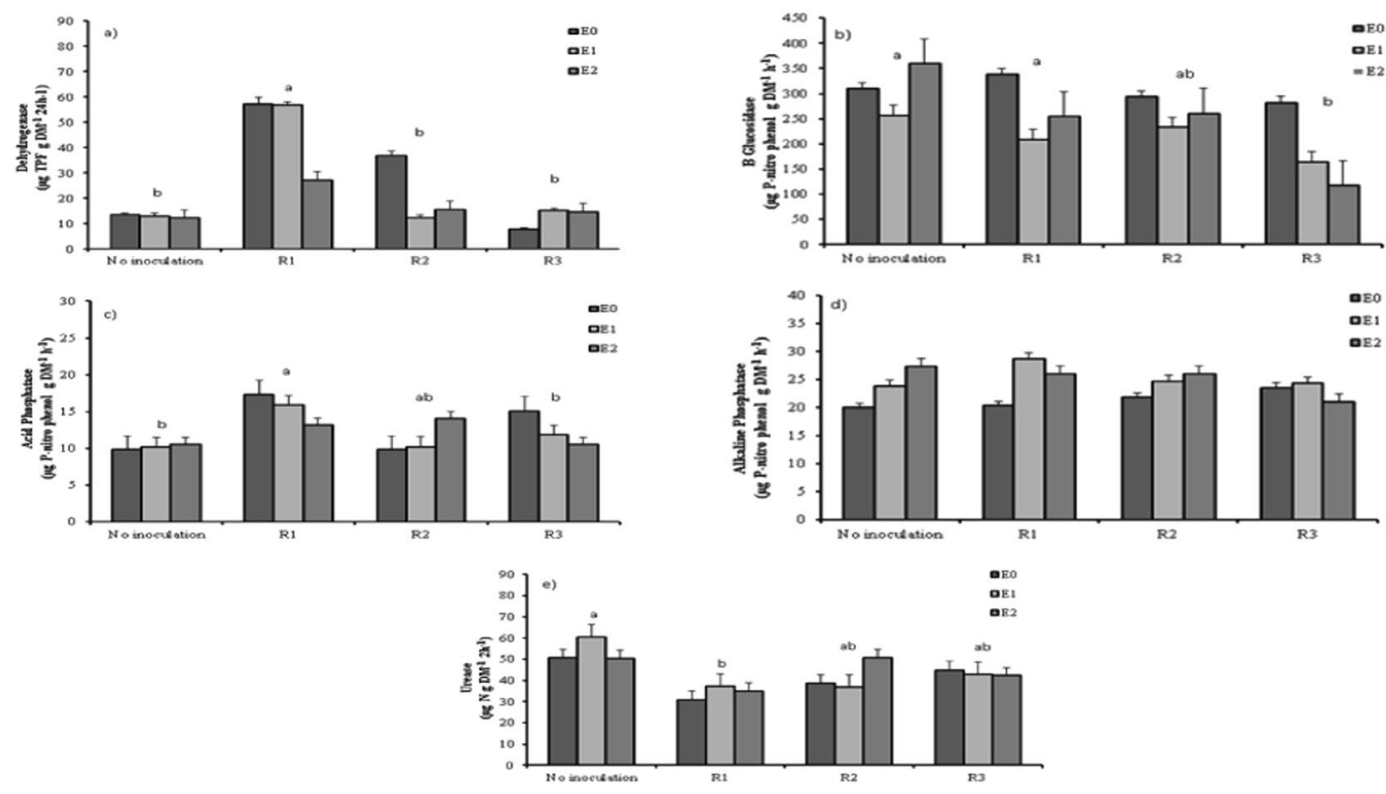

Figure 1. Effects of Rhizobium inoculation on (a) dehydrogenase enzyme activity, (b) $\beta$-Glucosidase enzyme activity, (c) acid phosphatase enzyme activity, (d) acid phosphatase enzyme activity, and (e) urease enzyme activity of soils amended with essential oil (E0: No essential oil; E1: essential oil (100 $\left.\mathrm{mg} \mathrm{kg}^{-1}\right)$, E2: essential oil (1000 $\mathrm{mg} \mathrm{kg}^{-1}$ ) and Rhizobium inoculation (R1: Rhizobium leguminosarum biovar phaseoli F7; R2: Rhizobium leguminosarum biovar phaseoli F83; R3: Rhizobium leguminosarum biovar phaseoli Ciat 889). Values are means \pm SE. Different letters indicate significant differences at $\mathrm{p}<0.001$. Post doc comparisons have been done between the different inoculation treatments.

\begin{tabular}{|l|l|l|l|l|l|l|}
\hline & \multicolumn{2}{|l|}{$\begin{array}{l}\text { Inoculation } \\
\text { treatment }\end{array}$} & \multicolumn{2}{l|}{$\begin{array}{l}\text { Essential oil } \\
\text { treatment }\end{array}$} & \multicolumn{2}{l|}{$\begin{array}{l}\text { Inoculation } \times \\
\text { Essential oil }\end{array}$} \\
\cline { 2 - 7 } Parameters & $\boldsymbol{F}$ & $\boldsymbol{p}$ & $\boldsymbol{F}$ & $\boldsymbol{p}$ & $\boldsymbol{F}$ & $\boldsymbol{p}$ \\
\hline Nodules & 217.3 & $p<0.001$ & n.s. & n.s. & 3.18 & $p<0.05$ \\
\hline Plant height & 9.7 & $p<0.001$ & n.s. & n.s. & n.s. & n.s. \\
\hline $\begin{array}{l}\text { Total plant } \\
\text { biomass }\end{array}$ & n.s. & n.s. & n.s. & n.s. & n.s. & n.s. \\
\hline $\begin{array}{l}\text { Plant N } \\
\text { content }\end{array}$ & n.s. & n.s. & n.s. & n.s. & n.s. & n.s. \\
\hline
\end{tabular}

Table 5. Two-way analyses of variance (ANOVA) for plant parameters of Phaseolus vulgaris L. treated with rhizobial inocula and essential oil as the source of variance. n.s.: Not significant.

of essential oils also induced a reduction of the $\beta$-Glu activity; higher values of this enzyme activity were observed in the E0 treatment than in E1 and E2.

Influence of essential oil and Rhizobium inoculation on plant properties. The effects of the application of different Rhizobium inoculation treatments on plant height are displayed in (Table 5). Plant height slightly increased with the application of Rhizobium strains; however, for R1 and R2 in combination with the lower essential oil dose (E1), a significant decrease was observed (Tables 3 and 5). Contrarily, for R3 a strong increase in plant height of almost $10 \mathrm{~cm}$ was observed compared to the other treatments (non-inoculated, R1, R2). However, we found reduced growth with the lower essential oils dose (E1) in comparison to E0 and E2. As expected, the number of nodules measured was influenced by the different inoculation treatments $(p<0.001)$. A higher average number of nodules was observed for R2 and R3 (44.3 and 50.4, respectively for both treatments), compared to R1 (29.5 nodules) and the non-inoculated control, for which no visible nodules were observed. Moreover, significant interaction between both treatments (Inoculation $\times$ Essential oil; $p<0.05$ ) was observed for the number of nodules (Tables 3 and 5) in the case of plants inoculated with R3, being the treatment R3 E1 (Table 3) the one presenting the highest nodule number. Although no significant effects of any of the applied treatments were observed for plant biomass (Table 3), it can be noticed that, on average, plants inoculated with Rhizobium strains (R1, R2, and R3) yielded a higher biomass than the control one (Table 5). Similarly, inoculation did not affect plant N-content (Table 5); however, plants grown in those soils inoculated with R1, R2 and R3 showed higher nitrogen contents $\left(2.4,2.2\right.$, and $2.7 \mathrm{~g} \mathrm{~kg}^{-1}$ respectively) than the non-inoculated control (approx. $\left.1.8 \mathrm{~g} \mathrm{~kg}^{-1}\right)$. 


\section{Discussion}

The presence of plant growth promoting bacteria (PGPB) in agricultural soils and their dynamics with plants has gained increasing interest among the scientific community thanks to the abilities of PGPB to solubilize nutrients $^{42-44}$. In fact, the application of Rhizobia and plant extracts in agriculture could be considered as a potential strategy for their application in organically managed and ecologically oriented farming systems. This is also true for the combined effect of Achillea millefolium essential oil and Rhizobium inoculation based on their potential influence on soil chemical, biological and plant growth parameters. Moreover, to our knowledge, there are no studies yet that have considered these factors.

For all of the combinations of Rhizobium with essential oil, a reduced abundance of both bacterial and fungal CFUs was measured in the present study. However, in the case of the R0E0 treatment, the bacterial CFUs were significantly higher than in the remaining treatments. Oils are known to have inhibitory effects against microbial populations and, in particular essential oil extracted from Achillea millefolium $L$ has shown antimicrobial and antifungal properties ${ }^{15}$. Although the antifungal effect in the treatments containing oil was significant, such effect was not as strong as that registered for bacteria.

In our study, it has been observed that even a small amount of essential oil had a positive effect in combination with Rhizobium to suppress both the bacterial and the fungal abundances. However, the specific oil component responsible for this suppression, and the underlying mechanisms behind this effect are not clear yet.

In line with our results, where we observed that the inoculation with 2 of the 3 strains led to a reduction in bacterial abundance, Christensen and Jakobsen ${ }^{45}$ also recorded a decrease in the bacterial abundance in cucumber plants after four weeks following inoculation with vesicular-arbuscular mycorrhizal fungi (AMF). Also, a pronounced antibacterial response of oil extract from Achillea millefolium on Staphylococcus species was reported ${ }^{46}$. Moreover, the inhibitory effect of essential oils on several plant pathogens has been observed in previous studies $^{47-49}$. However, other studies reported an enhanced soil metabolism and microbial activity following the application of essential oils ${ }^{50-52}$. In addition, it has been demonstrated that small amounts of Lavandula stoechas $L$. essential oil have a positive effect on mycorrhiza development ${ }^{53}$. Thus, the utilization of plants containing this essential oil in agriculture can be beneficial due to the natural origin of such oils, and their efficient action against pathogens based on the fact that they contain multiple active compounds, which hampers pathogen resistance development ${ }^{54}$.

Soil microbial activity, measured as basal respiration in this study, reached higher values when no essential oil was applied for R0 and R1; and decreased with the addition of essential oil except for the R3E2 treatment. Several researchers have documented an enhancement of soil respiration after the application of essential oils and their constituents ${ }^{50,55}$. A plausible explanation could be that the application of this type of oils induced a shift in the soil microbial community favouring the appearance of bacterial strains that are resistant and/or capable of catabolizing such components ${ }^{51}$. Assuming this, we would expect that some biologically active secondary metabolites derived from the extracted essential oil of Achillea millefolium $L$ might be able to alter soil microbial communities and promote the beneficial microbes involved in a rapid colonization of rhizosphere. However, the short duration of our experiment (45 days) made it impossible to confirm such observations.

In this experiment, the inoculation with different rhizobial strains induced a decrease in most of the measured soil enzyme activities, in particular $\mathrm{DH}$, which can be linked to the soil microbial biomass since its activity serves as an indicator for the physiologically active soil microbiota ${ }^{56,57}$. Indeed, some essential oils and the individual constituents do not cause an immediate effect on the soil microbiota, but rather seem to require a certain period of time, between 4 and 16 weeks depending on the studies, before increasing soil microbial abundance and basal respiration $^{50,55}$. However, it seems that R1 bacteria are more resistant than R2 and R3 bacteria to the effect resulting from the application of Achillea millefolium essential oil. Contrary to AlkP, AcdP activity reached its maximum level following R1 inoculation, while the lowest AcdP activity was observed in the no inoculation treatment. Although alkaline phosphatase is an enzyme produced during microbe-plant interactions ${ }^{58}$, it showed a positive response to the application of all Rhizobium inoculation and essential oil combinations compared to the no inoculation treatment. Nevertheless, numerous studies have demonstrated that the activity of alkaline phosphatase can remain unchanged after several treatments like those resulting from silvicultural activities ${ }^{59}$.

DH activity showed a significant decline depending on the bacterial species. In addition, DH activity which is primarily involved in the carbon cycle has a pivotal role in the enzyme system of all microorganisms ${ }^{57}$ that are linked with soil microbial respiration. The abovementioned activity decrease occurred after both inoculation and essential oil treatments. Both treatments also induced a reduction in soil microbial abundance that could explain the decrease of $\beta$-Glu activity, which seems to be highly related to the reduction in microbial carbon ${ }^{60}$. As UE activity was strongly affected by the inoculation treatments used in our study, the decrease in this enzyme activity could be due to nitrogen utilization by bacteria and reduction in soil $\mathrm{N}$ available forms ${ }^{61}$. In addition ${ }^{62}$, reported that the amendment with different natural products may act as an inhibitor of UE activity.

In contrast to our expectations, Rhizobium inoculation and the treatment with essential oil doses neither affected $\mathrm{NH}_{4}{ }^{+} \mathrm{N}, \mathrm{NO}_{3}{ }^{-} \mathrm{N}$ nor total $\mathrm{N}$ contents in soils, despite the increased number of root nodules in the inoculated treatments. However, since in the present study the whole plant was collected, the additional $\mathrm{N}$ accumulated in nodules was not added to the soil because it is released only during the decomposition of legume biomass. The rotating cropping system considers the release of $\mathrm{N}$ in situ either of the whole biomass, or of the roots and nodules $^{63}$. Another plausible explanation for the non-significant effect could be related to the short duration of the experiment. Nevertheless, it is important to highlight that plants amended with both treatments showed similar $\mathrm{NH}_{4}{ }^{+} \mathrm{N}, \mathrm{NO}_{3}{ }^{-} \mathrm{N}$, and total $\mathrm{N}$ contents than those from the treatments with no essential oil doses. This indicates that the application of these extracts affects soil microbiota in the short term rather than soil nutrient contents.

We observed that Rhizobium inoculation in combination with all of the rates of essential oil showed a positive response in terms of nodule number and plant height. Nevertheless, inoculating common bean and amending with essential oil did not result in a significant increase in plant biomass and plant $\mathrm{N}$ content. Previous studies 
have reported that Rhizobia are considered a main agent for $\mathrm{N}$ fixation in plants, root nodulation and crop growth ${ }^{64-66}$. Boddey et al ${ }^{67}$ found that inoculation of Cowpea with the Rhizobium strain BR 3299 significantly increased grain yield. Furthermore, as stated in Fan et al. ${ }^{68}$, inoculation of tomato plants with Plant Growth Promoting Rhizobacteria enhanced N and P uptake in the shoots. Contrary to these authors, and in line with our observations, Chekanai et al.$^{69}$ observed that inoculation with Rhizobium did not induce a positive response in plant biomass or grain yield in common bean (Phaseolus vulgaris L). However, it is known that essential oils are proven to be a thousand times less toxic than standard insecticides, and many of their constituents are not persistent in freshwater and can be metabolized by soil-borne microorganisms ${ }^{10}$.

\section{Conclusions}

In summary, we conclude that the application of Achillea millefolium essential oils alone or in combination with Rhizobium bacteria had an influence on soil productivity and the development of common bean (Phaseolus vulgaris L.). The biocide effect of the application of these essential oils was reflected in a decrease in bacterial and fungal CFUs as well as in basal respiration and soil enzymes activities. Moreover, such effects were stronger with higher oil concentrations. However, the applied essential oil did not seem to harm the effectivity of the used Rhizobium strains, in fact, its joint application increased the number of nodules and the plant height in the studied bean plants. Such effects were not accompanied by an increase in neither inorganic nor total N content in soil, which could be due to the duration of the study. In order to corroborate the positive results of this study, it would be necessary to perform further long-term studies under field conditions to determine the upscale application of Achillea millefolium essential oils, and their potential as additives suitable for organic farming and biologically managed soils.

Received: 1 August 2019; Accepted: 3 October 2019;

Published online: 23 October 2019

\section{References}

1. United Nations. World Population Prospects: The 2017 Revision, Key Findings and Advance Tables (2017).

2. Myers, J. R. \& Kmiecik, K. Common Bean: Economic Importance and Relevance to Biological Science Research. In The Common Bean Genome (eds Pérez de la Vega, M., Santalla, M. \& Marsolais, F.) 1-20 (2017)

3. Petry, N., Boy, E., Wirth, J. P. \& Hurrell, R. F. Review: The Potential of the Common Bean (Phaseolus vulgaris) as a Vehicle for Iron Biofortification. Nutrients 7, 1144-1173 (2015).

4. FAOSTAT. Food and Agriculture Organization of the United Nations, FAOSTAT. Food and agriculture data (2018).

5. McConnell, M. et al. Syntenic relationships among legumes revealed using a gene-based genetic linkage map of common bean (Phaseolus vulgaris L.). Theor Appl Genet 121, 1103-1116 (2010).

6. de Souza, J. E. B. \& de Brito Ferreira, E. P. Improving sustainability of common bean production systems by co-inoculating rhizobia and azospirilla. Agric Ecosyst Environm 237, 250-257 (2017).

7. Jones, F. A. Herbs: useful plants. J Roy Soc Med 89, 717-719 (1996).

8. Chao, L. K. et al. Study on the antiinflammatory activity of essential oil from leaves of Cinnamomum osmophloeum. J Agric Food Chem 53, 7274-8 (2005).

9. Lv, F., Liang, H., Yuan, Q. \& Li, C. In vitro antimicrobial effects and mechanism of action of selected plant essential oil combinations against four food-related microorganisms. Food Res Intern 44, 3057-3064 (2011).

10. Isman, M. B. Plant essential oils for pest and disease management. Crop Prot 19, 603-608 (2000).

11. Batish, D. R., Singh, H. P., Kohli, S. K. \& Kaur, S. Eucalyptus essential oil as a natural pesticide. Forest Ecol Manage 256, 2166-2174 (2008).

12. Lopez-Reyes, J. G., Spadaro, D., Prelle, A., Garibaldi, A. \& Gullino, M. L. Efficacy of Plant Essential Oils on Postharvest Control of Rots Caused by Fungi on Different Stone Fruits In Vivo. J Food Protect 76, 631-639 (2013).

13. Dunn, L. L. et al. Essential Oil Emulsions as Postharvest Sanitizers To Mitigate Salmonella Cross-Contamination on Peppers. J Food Protect 82, 159-163 (2019).

14. İscan, G. et al. Biological Activity and Composition of the Essential Oils of Achillea schischkinii Sosn. and Achillea aleppica DC. subsp. aleppica. J Agricult Food Chem 54, 170-173 (2006).

15. Stojanovic, G., Radulovic, N., Hashimoto, T. \& Palic, R. In vitro antimicrobial activity of extracts of four Achillea species: The composition of Achillea clavennae L. (Asteraceae) extract. J Ethnopharmacol 101, 185-190 (2005).

16. Knoth, J. L., Kim, S. H., Ettl, G. J. \& Doty, S. L. Effects of cross host species inoculation of nitrogen-fixing endophytes on growth and leaf physiology of maize. GCB Bioenergy 5, 408-418 (2013).

17. Knoth, J. L., Kim, S. H., Ettl, G. J. \& Doty, S. L. Biological nitrogen fixation and biomass accumulation within poplar clones as a result of inoculations with diazotrophic endophyte consortia. New Phytol 201, 599-609 (2014).

18. Erman, M., Ari, E., Togay, Y. \& Cig, F. Response of Field Pea (Pisum sativum sp Arvense L.) to Rhizobium Inoculation and Nitrogen Application in Eastern Anotolia. J Anim Vet Adv 8, 612-616 (2009).

19. Lu, J. K. et al. Co-existence of Rhizobia and Diverse Non-rhizobial Bacteria in the Rhizosphere and Nodules of Dalbergia odorifera Seedlings Inoculated with Bradyrhizobium elkanii, Rhizobium multihospitium-Like and Burkholderia pyrrocinia-Like Strains. Front Microbiol 8 (2017).

20. Schutz, L. et al. Improving Crop Yield and Nutrient Use Efficiency via Biofertilization-A Global Meta-analysis. Front Plant Sci 8 (2018).

21. Gopalakrishnan, S. et al. Plant growth promoting rhizobia: challenges and opportunities. 3 Biotech 5, 355-377 (2015).

22. van Heerwaarden, J. et al. Soyabean response to rhizobium inoculation across sub-Saharan Africa: Patterns of variation and the role of promiscuity. Agric, Ecosyst \& Environm 261, 211-218 (2018).

23. Korir, H., Mungai, N. W., Thuita, M., Hamba, Y. \& Masso, C. Co-inoculation Effect of Rhizobia and Plant Growth Promoting Rhizobacteria on Common Bean Growth in a Low Phosphorus Soil. Front Plant Sci 8 (2017).

24. Alam, F. et al. Effect of Rhizobium sp. BARIRGm901 inoculation on nodulation, nitrogen fixation and yield of soybean (Glycine max) genotypes in gray terrace soil. Biosci Biotech Bioch 79, 1660-1668 (2015).

25. Fall, D. et al. Rhizobial Inoculation Increases Soil Microbial Functioning and Gum Arabic Production of 13-Year-Old Senegalia senegal (L.) Britton, Trees in the North Part of Senegal. Front Plant Sci 7 (2016).

26. IUSS Working Group WRB. World Reference Base for Soil Resources 2014, update 2015 International soil classification system for naming soils and creating legends for soil maps. 192 (2015).

27. Somasegaran, P. \& Hoben, H. J. Handbook for Rhizobia: Methods in Legumes-Rhizobium. Springer, Heidelberg (1994).

28. Bouyoucos, G. J. A Recalibration of the Hydrometer Method for Making Mechanical Analysis of Soils. Agron J 43, 434-438 (1951). 
29. Sumner, M. E. \& Miller, W. P. Cation Exchange Capacity and Exchange Coefficients. In Methods of soil analysis, part 3. Chemical Methods (ed. Sparks, D. L.) 1201-1230 (1996).

30. Nelson, D. W. \& Sommers, L. E. Total carbon, organic carbon and organic matter. In Methods of soil analysis, part 2. Chemical and Microbiological Properties (eds Miller, R. H. \& Keeney, D. R.) 539-579 (1982).

31. Bremmer, J. M. \& Keeney, D. R. Steam distillation methods for determination of ammonium, nitrate and nitrite. Analytica Chimica Acta 32, 485-495 (1965).

32. Olsen, S. R. \& Sommers, L. E. Phosphorus. In Methods of soil analysis, part 2. Chemical and microbiological properties (eds Miller, R. H. \& Keeney, D. R.) 403-430 (1982).

33. Wollum, A. G. Cultural methods for soil microorganisms, In: Miller, R. H. \& Keeney, D. R. (Eds). In Methods of Soil Analysis, Part 2. Chemical and Microbiological Properties 781-802 (Am. Soc. Agron, 1982).

34. Madigan, M. T., Martinko, J. M. \& Brock, R. D. Culture-dependen analyses of microbial communities. Biology of microorganisms (2006).

35. Canbolat, M. Y., Bilen, S., Cakmakci, R., Sahin, F. \& Aydin, A. Effect of plant growth-promoting bacteria and soil compaction on barley seedling growth, nutrient uptake, soil properties and rhizosphere microflora. Biol Fert Soils 42, 350-357 (2006).

36. Pratt, R. G. Fungal population levels in soils of commercial swine waste disposal sites and relationships to soil nutrient concentrations. Appl Soil Ecol 38, 223-229 (2008).

37. Vestergård, M. et al. The relative importance of the bacterial pathway and soil inorganic nitrogen increase across an extreme woodash application gradient. GCB Bioenergy 10, 320-334 (2018).

38. Islam, K. R. \& Weil, R. R. Land use effects on soil quality in a tropical forest ecosystem of Bangladesh. Agr Ecosyst Environ 79, 9-16 (2000).

39. Tabatabai, M. A. Methods of soil analysis, part 2. Microbiological and biochemical properties. In (ed. Weaver, R. W. et al.) 801-834 (1994).

40. Tabatabai, M. A. \& Bremner, J. M. Assay of urease activity in soils. Soil Biol Biochem 4, 479-487 (1972).

41. Jones, J. B. Laboratory guide for conducting soil tests and plant analysis. In Conducting soil tests and plant analysis 363 (CRC Press, 2001).

42. Rajkumar, M., Ae, N., Prasad, M. N. V. \& Freitas, H. Potential of siderophore-producing bacteria for improving heavy metal phytoextraction. Trends Biotechnol 28, 142-149 (2010).

43. Minaxi, Nain, L., Yadav, R. C. \& Saxena, J. Characterization of multifaceted Bacillus sp RM-2 for its use as plant growth promoting bioinoculant for crops grown in semi arid deserts. Appl Soil Ecol 59, 124-135 (2012).

44. Oteino, N. et al. Plant growth promotion induced by phosphate solubilizing endophytic Pseudomonas isolates. Front Microbiol 6 (2015).

45. Christensen, H. \& Jakobsen, I. Reduction of Bacterial-Growth by a Vesicular-Arbuscular Mycorrhizal Fungus in the Rhizosphere of Cucumber (Cucumis-Sativus L). Biol Fert Soils 15, 253-258 (1993).

46. Issabeagloo, E., Taghizadieh, M. \& Abri, B. Antimicrobial effects of yarrow (Achillea millefolium) essential oils against Staphylococcus spp. African J Pharm Pharmacol 6, 2895-2899 (2012).

47. Karamanoli, K., Vokou, D., Menkissoglu, U. \& Constantinidou, H.-I. Bacterial Colonization of Phyllosphere of Mediterranean Aromatic Plants. J Chem Ecol 26, 2035-2048 (2000).

48. Daferera, D. J., Ziogas, B. N. \& Polissiou, M. G. The effectiveness of plant essential oils on the growth of Botrytis cinerea, Fusarium sp and Clavibacter michiganensis subsp michiganensis. Crop Prot 22, 39-44 (2003).

49. Kadoglidou, K. et al. Inhibitory and stimulatory effects of essential oils and individual monoterpenoids on growth and sporulation of four soil-borne fungal isolates of Aspergillus terreus, Fusarium oxysporum, Penicillium expansum, and Verticillium dahliae. Eur J Plant Pathol 130, 297-309 (2011).

50. Vokou, D. \& Liotiri, S. Stimulation of soil microbial activity by essential oils. Chemoecology 9, 41-45 (1999).

51. Vokou, D., Chalkos, D., Karamanlidou, G. \& Yiangou, M. Activation of soil respiration and shift of the microbial population balance in soil as a response to Lavandula stoechas essential oil. J Chem Ecol 28, 755-768 (2002).

52. Owen, S. M., Clark, S., Pompe, M. \& Semple, K. T. Biogenic volatile organic compounds as potential carbon sources for microbial communities in soil from the rhizosphere of Populus tremula. Fems Microbiol Lett 268, 34-39 (2007).

53. Hassiotis, C. N. \& Orfanoudakis, M. The impact of Lavandula stoechas L. degradation on arbuscular mycorrhizal fungi, in a Mediterranean ecosystem. Appl Soil Ecol 126, 182-188 (2018).

54. Chalkos, D. et al. Mentha spicata and Salvia fruticosa composts as soil amendments in tomato cultivation. Plant Soil 332, 495-509 (2010).

55. Vokou, D. \& Margaris, N. S. Decomposition of Terpenes by Soil-Microorganisms. Pedobiologia 31, 413-419 (1988).

56. Wolińska, A. \& Stępniewska, Z. Dehydrogenase Activity in the Soil Environment. In Dehydrogenases (ed. Prof. Rosa Angela Canuto) 183-210 (InTech, 2012).

57. Subhani, A., Changyong, H., Zhengmiao, X., Min, L. \& El-ghamry, A. M. Impact of Soil Environment and Agronomic Practices on Microbial/Dehydrogenase Enzyme Activity in Soil. A Review. Pakistan J Biol Sci 4, 333-338 (2001).

58. Nakas, J. P., Gould, W. D. \& Klein, D. A. Origin and Expression of Phosphatase-Activity in a Semiarid Grassland Soil. Soil Biol Biochem 19, 13-18 (1987).

59. Perie, C. \& Munson, A. D. Ten-year responses of soil quality and conifer growth to silvicultural treatments. Soil Sci Soc Am J 64, $1815-1826(2000)$.

60. Turner, B. L., Hopkins, D. W., Haygarth, P. M. \& Ostle, N. $\beta$-Glucosidase activity in pasture soils. Appl Soil Ecol 20, 157-162 (2002).

61. Zhang, Q. et al. Effects of fomesafen on soil enzyme activity, microbial population, and bacterial community composition. Environ Monit Assess 186, 2801-2812 (2014).

62. Patra, D. D., Kiran, U. \& Pande, P. Urease and nitrification retardation properties in natural essential oils and their by-products. Commun Soil Sci Plan 37, 1663-1673 (2006).

63. Peoples, M. B. \& Craswell, E. T. Biological nitrogen fixation: Investments, expectations and actual contributions to agriculture. Plant Soil 141, 13-39 (1992).

64. Graham, P. H. \& Vance, C. P. Legumes: Importance and Constraints to Greater Use. Plant Physiol. 131, 872 (2003).

65. Vessey, J. K. Plant growth promoting rhizobacteria as biofertilizers. Plant Soil 255, 571-586 (2003).

66. Hayat, R., Ali, S., Amara, U., Khalid, R. \& Ahmed, I. Soil beneficial bacteria and their role in plant growth promotion: a review. Ann Microbiol 60, 579-598 (2010).

67. Boddey, R. M. et al. Cowpea (Vigna Unguiculata) Crops in Africa Can Respond to Inoculation with Rhizorium. Exp Agr 53, 578-587 (2017).

68. Fan, X. H. et al. Effects of Plant Growth-Promoting Rhizobacteria and N Source on Plant Growth and N and P Uptake by Tomato Grown on Calcareous Soils. Pedosphere 27, 1027-1036 (2017).

69. Chekanai, V., Chikowo, R. \& Vanlauwe, B. Response of common bean (Phaseolus vulgaris L.) to nitrogen, phosphorus and rhizobia inoculation across variable soils in Zimbabwe. Agric Ecosyst Environ 266, 167-173 (2018). 


\section{Acknowledgements}

The authors thank Dr. Lyudmila Lyubenova from Helmholtz Zentrum München for their valuable help during the greenhouse and laboratory work. Veysel Turan has been supported by a postdoctoral research grant from The Scientific and Technological Research Council of Turkey (TUBITAK, grant number, 1059B191601133) and a doctoral grant from The Council of Higher Education, Turkey (CoHE, grant number: 82444403-207.04/26187).

\section{Author contributions}

All authors (V.T., P.S., S.B., H.I. and M.F.D.J.) contributed jointly to the reported work in the manuscript. V.T. performed most of the experiments. Data analysis was performed by V.T. and M.F.D.J. P.S. and S.B. co-supervised V.T. in this research. All authors read and approved the final manuscript.

\section{Competing interests}

The authors declare no competing interests.

\section{Additional information}

Correspondence and requests for materials should be addressed to V.T.

Reprints and permissions information is available at www.nature.com/reprints.

Publisher's note Springer Nature remains neutral with regard to jurisdictional claims in published maps and institutional affiliations.

(c) (i) Open Access This article is licensed under a Creative Commons Attribution 4.0 International License, which permits use, sharing, adaptation, distribution and reproduction in any medium or format, as long as you give appropriate credit to the original author(s) and the source, provide a link to the Creative Commons license, and indicate if changes were made. The images or other third party material in this article are included in the article's Creative Commons license, unless indicated otherwise in a credit line to the material. If material is not included in the article's Creative Commons license and your intended use is not permitted by statutory regulation or exceeds the permitted use, you will need to obtain permission directly from the copyright holder. To view a copy of this license, visit http://creativecommons.org/licenses/by/4.0/.

(C) The Author(s) 2019 